\title{
Palliative Balloon Pulmonary Valvotomy in Tetralogy of Fallot: Is There a Role in 2021?
}

\author{
Supratim Sen ${ }^{1}$ and Bharat Dalvi ${ }^{1,2, *}$ \\ 1 Department of Pediatric Cardiology, SRCC Children's Hospital, Mumbai 400034, India; \\ supratim.sen.dr@narayanahealth.org \\ 2 Glenmark Cardiac Centre, Mumbai 400028, India \\ * Correspondence: bharatdalvi@hotmail.com; Tel.: +91-22-24335055
}

check for updates

Citation: Sen, S.; Dalvi, B. Palliative Balloon Pulmonary Valvotomy in Tetralogy of Fallot: Is There a Role in 2021? Hearts 2021, 2, 224-233. https://doi.org/10.3390/ hearts2020018

Academic Editor:

Matthias Thielmann

Received: 26 February 2021

Accepted: 15 April 2021

Published: 20 April 2021

Publisher's Note: MDPI stays neutral with regard to jurisdictional claims in published maps and institutional affiliations.

Copyright: (c) 2021 by the authors. Licensee MDPI, Basel, Switzerland. This article is an open access article distributed under the terms and conditions of the Creative Commons Attribution (CC BY) license (https:/ / creativecommons.org/licenses/by/ $4.0 /)$.

\begin{abstract}
The current treatment practice for Tetralogy of Fallot (TOF) is to undertake complete surgical repair between 6-9 months of age with excellent immediate and long-term results. In patients with increased cyanosis or frequent cyanotic spells, younger age of complete repair as early as 3 months is usually acceptable. Although neonatal TOF repair is reported with good immediate survival from a few centres, post-operative morbidity is significant, and the hospital stay is prolonged. Hence, in neonates and small term and preterm infants with severe cyanosis, palliative procedures such as modified Blalock-Taussig (BT) shunt, ductal stenting, right ventricular outflow tract (RVOT) stenting and balloon pulmonary valvotomy (BPV) have been reported. With the development of low-profile stents, an increasing clinician experience and more predictable outcome with both duct and RVOT stenting, these procedures have gained popularity as the preferred palliations for TOF at most centres. We reviewed the literature to analyse whether BPV for TOF palliation, a technique first reported three decades ago, still has a role in the present era of paediatric cardiac care. In this review, we have concluded that BPV has very specific indications in patients with TOF, with predominantly valvar pulmonary stenosis, and may be a preferred option over other palliative strategies in hypoxemic preterm or low-birth weight infants.
\end{abstract}

Keywords: Tetralogy of Fallot; balloon pulmonary valvotomy; transcatheter palliation

\section{Introduction}

Tetralogy of Fallot is the most common cyanotic congenital heart defect comprising $3.5 \%$ of all CHD [1]. Tetralogy constitutes a combination of a ventricular septal defect, aortic override, muscular obstruction of the right ventricular outflow tract, and right ventricular hypertrophy, secondary to anterior and cephalad deviation of the septal insertion of the outlet septum, relative to the septomarginal trabeculation [1]. The ideal age of elective intracardiac repair for TOF has gradually decreased over the last three decades. Neonatal repair has been described [2,3] with no increase in mortality, although the morbidity and hospital stay are significantly higher than surgery in older infants. Most centres, the world over, undertake elective TOF repair between 3-9 months age, based on the lowest mortality in this age group [2,4].

In the neonates and infants who are symptomatic with low saturations or frequent cyanotic spells, where the institutional policy precludes early intracardiac repair, palliative options include surgical modified BT shunt, RVOT stenting, ductal stenting, and BPV [5].

We reviewed the recent literature to ascertain the role of palliative BPV in the present era of paediatric cardiac care.

\section{Early Reports of BPV}

Balloon pulmonary valvotomy, for isolated valvar pulmonary stenosis, was first reported by Kan in 1982 [6]. In 1987 and 1988, Qureshi and colleagues published their results with BPV in Tetralogy of Fallot [7,8], which were promising. Between 1983 and 
1986, 15 infants underwent BPV (Table 1). The mean age at first procedure was 3.3 months. The authors recommended balloon diameter to pulmonary annulus ratio of $133-140 \%$. Adequate non-surgical palliation was achieved in $73 \%$ of infants, and four of them, later, had elective total correction.

However, this was an era where complete repair for TOF was performed after two years of age with mortality of $1-5 \%$. Hence, the authors were comparing outcomes of BPV in infants with modified BT shunt.

A decade later, in 1995, Sluysmans et al., in their series from Belgium, analysed the results of BPV in 19 infants with TOF (Table 1) [9]. The authors demonstrated that balloon dilatation clearly resulted in a rise of pulmonary valve dimensions, with a mean gain of 1.74 standard deviation immediately after dilatation and $2.17 \mathrm{SD}$ before surgical correction. The balloonto-annulus ratio correlated significantly with the change in pulmonary annulus diameter, with the biggest increase observed with a balloon-to-annulus ratio $\geq 1.5$. To avoid potential complications with large balloons, the authors recommended a balloon-to-annulus ratio of 1.5-2. The study concluded that BPV was associated with a 30- $40 \%$ decrease in the need for transannular patch during the time of the corrective surgery for TOF, and recommended consideration of balloon dilation for cyanotic infants with pulmonary annulus smaller than $-3 \mathrm{SD}$ below normal.

The growth of the pulmonary annulus and pulmonary arteries post BPV was not consistently and uniformly demonstrated in other studies from the same era, especially when accounting for proportional pulmonary annular and arterial growth with age on follow-up $[10,11]$. Heusch et al. observed that, post-BPV, there was a parallel growth but no 'catch up' in growth of the pulmonary arteries in most of their patients [10].

\section{Present Era}

In contemporary series, the mortality of intracardiac repair of Tetralogy of Fallot is $2-3 \%$ [3]. Internationally, there is a general consensus that elective repair for TOF should ideally be performed between 3 to 9 months age [12].

Prior to the age of 3 months, treatment strategies differ between centres. For neonates or young infants, who have significant cyanosis or frequent cyanotic spells, where symptoms preclude waiting for 3-6 months, the options are early primary intracardiac repair versus a surgical or transcatheter palliation. The surgical palliation, the modified BT shunt, a procedure first described in the 1940s, still has significant mortality risk. In a study analysing the STS database (The Society of Thoracic Surgeons-Congenital Heart Surgery Database, North America) results from 2002-2009, neonatal mortality was 7.3\% [3]. Even in those patients with biventricular circulation, such as TOF, modified BT shunt mortality was $5.1 \%$ [3,13]. Between 2002 and 2007, a study by Al Habib et al. which analysed data from the STS database revealed neonatal TOF repair early mortality of $7.8 \%$ and neonatal BT shunt mortality of $6.2 \%[3,4]$.

Wilder and colleagues compared outcomes of transcatheter palliation with early primary intracardiac repair in symptomatic patients, prior to 3 months age, for patients treated at the Hospital for Sick Children, Toronto, from 2000 to 2012 [12]. In this cohort, 42 patients underwent early primary repair at less than 3 months age, and 28 underwent palliative catheter intervention. This latter intervention group comprised 18 RVOT stents, 9 RVOT balloon dilations, and 1 ductal stent. Two patients in this group required early TOF surgery at 1.5 and 2 months age, while definitive repair was successfully delayed in the rest. The median age at intervention was 13 days (range 1-306) for the transcatheter intervention group and 50 days (range 9-90) for the early surgery group. The authors mentioned an institutional preference of early total surgical repair, even for symptomatic infants less than three months age. However, in the presence of adverse surgical risk factors such as low birth weight neonates, sepsis, and coexisting congenital malformations, transcatheter palliation was undertaken. There was one death each in the early intracardiac repair and catheter palliation group. In the groups who underwent early total repair and transcatheter palliation, reoperation rates were similar, except in neonates, where early repair was associated with increased reoperation risk. Risk-adjusted freedom from 
reintervention was $76 \%$ for early repair and $53 \%$ for transcatheter palliation at 10 years. The authors concluded that both these strategies for treating TOF, in neonates and young infants, are comparable and reasonable options.

\section{Role of Transcatheter Interventions for Palliation in Infants with TOF}

Right ventricular outflow tract stenting, ductal stenting, and BPV are the three transcatheter options available for palliation in infants $<3$ months of age. Each of these procedures have their advantages and limitations. While BPV was the earliest interventional palliation described for TOF, it has limited utility in patients with predominantly infundibular obstruction. RVOT stenting has become one of the preferred transcatheter palliations with better branch pulmonary arterial growth as compared to modified BT shunts [3,14-16]. Ductal stenting is only feasible when the arterial duct is still patent at the time the clinician decides the need for the palliative procedure. In TOF, often, the duct may have closed spontaneously or may be associated with branch pulmonary artery stenosis, making ductal stenting a less frequently employed palliative strategy in these patients.

Table 1 summarizes findings from various important studies describing BPV in TOF spanning three decades.

\section{BPV vs. RVOT Stenting}

The nature of pulmonary stenosis in Tetralogy of Fallot is at multiple levels due to [1]:

- Anterocephalad deviation of the outlet septum resulting in subpulmonary obstruction

- Hypertrophy of septoparietal trabeculations in the subvalvular region

- A hypoplastic pulmonary valve annulus

- The pulmonary valve itself may be bicuspid and stenotic

- Supravalvar narrowing and hypoplasia of the pulmonary artery branches

Balloon pulmonary valvotomy would logically work best when there is predominantly valvar pulmonary stenosis in a patient with an adequately sized pulmonary annulus. Often, in newborns and young infants, the degree of infundibular hypertrophy is less, and hence BPV may yield satisfactory results despite this theoretically multilevel obstruction in Tetralogy of Fallot. Nevertheless, RVOT stenting undoubtedly would address the infundibular stenosis, and to some extent even the pulmonary annular hypoplasia, better and more predictably than static balloon dilation.

\section{Technique of BPV}

Transcatheter BPV in TOF is preferably carried out under elective intubation and general anaesthesia. The anaesthesia team should be prepared to deal with persistent and refractory cyanotic spells and hemodynamic instability during the procedure. Routine precautions include adequate hydration and having pre-loaded appropriate doses of intravenous Propranolol or Metoprolol and Morphine along with other emergency drugs ready in the anaesthesia drug-tray to expedite emergency administration in case of cyanotic spells and hemodynamic compromise. Access is either via the femoral vein or the right internal jugular vein (IJV). The IJV access is preferred in patients weighing less than $2.5 \mathrm{~kg}$ [16]. After the access, $100 \mathrm{U} / \mathrm{kg}$ of Heparin and prophylactic antibiotics are administered.

Entering the right ventricle in small newborns may be difficult. Use of a long sheath and hard end of the guide wire, curved appropriately, help in navigating the catheter into the RV.

After entering the right ventricle with a $4 \mathrm{~F}$ Judkins right coronary catheter [2], the RVOT is delineated with a hand injection of contrast in the lateral view and RAO cranial view (right anterior oblique $30^{\circ}$, cranial tilt $20^{\circ}$ ) [16]. The catheter is then carefully maneuverer into the RVOT from the RV apex with a slow withdrawal and clockwise rotation. With the catheter in the RVOT, the pulmonary valve is usually crossed with a 0.014 " coronary guide wire [2], which is then placed deep in the left or right pulmonary artery. For BPV, the remaining procedure is standard, with passing of a $2 \mathrm{~cm}$ Tyshak-mini (NuMED Inc., Hopkinton, NY, USA) or similar low profile balloon with diameter 1.5 to 2 times the pulmonary annulus over the coronary guide wire. 


\section{In Which Situations Would BPV Be Preferable to RVOT Stenting and Vice Versa?}

Once the coronary guide-wire is in a stable position across the stenosed pulmonary valve into one of the distal branch pulmonary arteries, proceeding with RVOT stenting instead of balloon pulmonary valvotomy is not technically challenging. The technical difference between balloon dilation and RVOT stenting at this stage in the procedure is that the balloon can be taken directly through the groin or IJV introducer sheath, whereas it is preferable to take a stent through a guiding Judkins Right (JR) catheter or a long sheath. The workhorse coronary guide-wire is not adequate for positioning a long sheath or guide JR in the RVOT, and a stiffer and bigger guide wire (such as a Balanced Middleweight coronary wire or a $0.021^{\prime \prime}$ Teflon guide-wire) is required.

In a smaller baby weighing $2-2.5 \mathrm{~kg}$, it is preferable to limit the introducer sheath size to $5 \mathrm{~F}$, and in a preterm baby weighing less than $2 \mathrm{~kg}$, to $4 \mathrm{~F}$. Additionally, in small babies weighing less than $2 \mathrm{~kg}$, passing a stiff, long sheath or Guiding JR catheter across the tricuspid valve, right ventricle and into the RVOT may itself stent the heart and cause hemodynamic instability. Hence, the most common situation where one would prefer BPV over RVOT stenting would be a preterm baby weighing less than $2 \mathrm{~kg}$.

Similarly, in an infant with significant cyanosis and/or cyanotic spells during the procedure, a quicker BPV is preferable to avoid hemodynamic compromise. However, in this setting, it is prudent to leave the coronary wire across the RVOT after the BPV and balloon removal and confirm adequate saturations. If significant infundibular stenosis and low saturations persist despite an adequate BPV, one could then proceed with RVOT stenting.

Nevertheless, our routine preference of transcatheter palliation in an infant TOF without weight and clinical limitations would be RVOT stenting. In our practice, we do not advocate a trial of BPV followed by RVOT stenting if echocardiogram and angiograms suggest multilevel RVOT obstruction which would have a suboptimal result with BPV. The reason for this is twofold. Firstly, the BPV itself may precipitate cyanotic spells, making attempts at RVOT stenting in a clinically unstable baby risky. Second, if we plan to anchor the RVOT stent across the pulmonary annulus, prior BPV could increase potential risk of stent migration by enlarging the valvar constriction, or force use of an oversized RVOT stent leading to pulmonary overcirculation.

In patients with associated coronary anomalies with a major coronary crossing the RVOT anteriorly, previous studies have demonstrated no added risk of coronary compression with RVOT stents [17]. Hence, stenting the native RVOT is not contraindicated in TOF with coronary anomalies, and BPV is not routinely preferred over RVOT stenting in these patients.

\section{Alternate Approaches for BPV}

In small infants with TOF with pulmonary atresia, PDA stenting is the standard transcatheter intervention. A hybrid approach with sternotomy, transventricular puncture of the right ventricular outflow tract and atretic pulmonary valve, followed by balloon dilation has been described in small infants with TOF-pulmonary atresia with hypoplastic pulmonary trunk [18].

In a few recent series, intraoperative BPV, during repair of TOF, has been evaluated as a pulmonary valve sparing technique [19-21]. Vida and colleagues reported their early experience in 18 patients in 2012 [19], where the median age at surgery was 3.1 months and median preoperative pulmonary valve Z-score was -2.5 . Of these 18 patients, 16 had initial preservation of the pulmonary annulus. On mid-term follow up, (median follow-up time of 1.4 years), reoperation was needed in one patient, 3 months after repair, due to significant residual subvalvar RVOT obstruction. In the remaining 15 patients, the median PV Zscore was 0 and median peak RVOT gradient was $20 \mathrm{~mm} \mathrm{Hg}$. There was no pulmonary regurgitation in seven patients, mild regurgitation in seven patients and moderate in one.

However, these findings were not replicated in a follow up study from the Boston Children's Hospital reported by Hofferberth et al. [21]. In this study, 162 consecutive patients with TOF underwent valve-sparing repair with intraoperative balloon dilation under 1 year of age. Mean preoperative PV z-score was $-2.21+/-0.55$. Median age at 
surgery was 98 days (interquartile range [IQR], 72-126) and median follow-up was 2.5 years (IQR, 0.6-4.9). Median maximal balloon diameter to annulus ratio was 1.32 (interquartile range 1.18 to 1.45$)$. Twenty-five patients (15.4\%) required reintervention for residual valvular stenosis. Freedom from at least moderate pulmonary regurgitation was 77\%, 61\%, and $43 \%$ at 1,3 , and 5 years post-repair. The authors concluded that this technique led to similar RV dilation as transannular patch at midterm follow-up.

\section{Complications of BPV}

During the procedure, the most common complication is a cyanotic spell, which usually responds to fluid boluses and medical management. Bradycardia, hypotension and ST-T changes can occur while crossing the RVOT [2,7]. Ventricular ectopics and arrhythmias may be provoked during the manipulation of the catheter in the RV and one needs to be careful and aware of this to prevent a sustained ventricular tachycardia. Adequate hydration and optimization of electrolytes, acid-base balance, and oxygenation also help in preventing this complication apart from gentle manipulation of the catheter.

Occasionally, while entering the RV or turning the catheter to look at the RVOT, the AV node may get injured, causing bradycardia. In some sick newborns, this bradycardia with a loss of AV synchrony results in severe hemodynamic compromise and worsening of hypoxemia. Emergency administration of intravenous Atropine and corticosteroids may help in this situation. Rarely, insertion of a temporary pacing catheter via the venous access for right ventricular pacing may be required to stabilize the deranged hemodynamics.

During an attempted crossing of the pulmonary valve, perforation of the RVOT anteriorly [2,5] has been described. This can lead to tamponade, emergency surgery, and death. This complication can occur more often while attempting to cross the pulmonary valve with a Terumo Glidewire (Terumo Medical Corporation, Sommerset, NJ, USA). Hence, it is preferable to position a JR catheter in the RVOT and cross the valve either with the catheter directly or with a floppy tip 0.014 " coronary guide-wire.

Other major post-procedure complications reported include sepsis, endocarditis, seizures, complete heart block, and pulmonary edema $[5,7,11]$.

In TOF patients with primarily valvar pulmonary stenosis, BPV can potentially cause pulmonary overcirculation, pulmonary edema and worsening cardiac failure [7,11]. However, in our experience, these complications are rare with balloon-annulus ratio of 1.5-2, due to the commonly associated pulmonary annular hypoplasia.

Post-valvotomy, although, moderate or severe pulmonary regurgitation is the rule, it is well tolerated in the short and intermediate term. Recurrence of stenosis is more common following BPV as compared to RVOT stenting. It is dealt with a repeat BPV, RVOT stenting, or a surgical intervention.

\section{When Not to Consider BPV or RVOT Stenting in TOF}

TOF with a doubly committed subarterial VSD will have predominantly valvar pulmonary stenosis as there is no significant infundibular component. In a report from Great Ormond Street Hospital, London in 2007, Kostolny et al. reported an experience with $\mathrm{BPV}$ in a $2.2 \mathrm{~kg}$ neonate with this anatomy [22]. The pulmonary annulus measured $8 \mathrm{~mm}$ and BPV was performed with a $7 \mathrm{~mm}$ Tyshak-II (NuMED Inc., Hopkinton, NY, USA) balloon. Although the saturations improved, severe aortic regurgitation was noted on echocardiography. During emergency surgery, a longitudinal tear was seen on the right coronary sinus of the aortic root. The authors highlighted with this case example that in the absence of muscular outlet septum in a TOF with doubly committed VSD, the facing leaflets of the aortic and pulmonary valves are in fibrous continuity. Hence, any splitting or controlled tear of the pulmonary valve leaflets during BPV in these patients has the potential to extend into the adjacent wall of the aortic valve sinus.

For this same reason, stenting of the RVOT is contraindicated in TOF with doubly committed VSD [23]. 
Table 1. Review of Literature.

\begin{tabular}{|c|c|c|c|c|c|c|c|}
\hline $\begin{array}{l}\text { Author and } \\
\text { Publication }\end{array}$ & Era & Age & Weight & Baseline SpO2 & $\begin{array}{l}\text { Post Balloon } \\
\text { SpO2 }\end{array}$ & Post BPV Course & Complications \\
\hline $\begin{array}{c}\text { Qureshi et al. } \\
\text { Br Heart J } 1988 \text { [7] } \\
15 \text { patients, } \\
24 \text { procedures }\end{array}$ & 1983-1986 & $\begin{array}{l}3.3 \text { months } \\
(0.5- \\
9 \text { months })\end{array}$ & & $\begin{array}{c}\text { Mean } 75 \% \\
\text { (range } 46-97 \%)\end{array}$ & $\begin{array}{c}\text { Mean } 87 \% \text { (range } \\
65-98 \% \text { ) }\end{array}$ & $\begin{array}{l}4 \text { systemic to PA shunts } 1.6 \text { months } \\
\text { (range } 0-3 \text { months) after dilatation. } \\
4 \text { corrective operations } 6-10 \text { months } \\
\text { (mean } 8 \text { months) after dilatation. Six- } \\
\text { no further intervention after a mean } \\
\text { follow up of } 12.9 \text { months. }\end{array}$ & $\begin{array}{l}1 \text { transient pulmonary edema, } \\
1 \text { worsening cyanosis requiring a } \\
\text { Waterston shunt, } 1 \text { infective } \\
\text { endocarditis which subsequently died. }\end{array}$ \\
\hline \multirow{2}{*}{$\begin{array}{l}\text { Sreeram et al. } \\
\text { JACC } 1991[11]\end{array}$} & \multirow{4}{*}{ 1983-1989 } & \multirow{4}{*}{$\begin{array}{l}\text { Median age } \\
\text { of } 5 \text { months } \\
\text { (range } 0.03 \\
\text { to } \\
52 \text { months) }\end{array}$} & & \multirow{4}{*}{$\begin{array}{c}74 \% \\
\text { (range } 46-99 \%)\end{array}$} & \multirow{4}{*}{$\begin{array}{c}90.5 \% \\
\text { (range } 45-100 \%)\end{array}$} & $\begin{array}{l}\text { Procedure unsuccessful in } 3 \text { patients } \\
\text { (valve could not be crossed). } \\
18 \text { patients required an aortopulmonary } \\
\text { shunt after their initial BPV. }\end{array}$ & \multirow{4}{*}{$\begin{array}{l}2 \text { patients received an aortopulmonary } \\
\text { shunt for significant cyanosis during } \\
\text { the same hospital admission. } 1 \text { patient } \\
\text { developed transient pulmonary edema } \\
\text { after the procedure and required } \\
\text { mechanical ventilation. } 1 \text { patient } \\
\text { developed group D streptococcal } \\
\text { septicemia. } 2 \text { patients (balloon/annulus } \\
\text { ratio }>2.5 \text { ) developed cardiac } \\
\text { tamponade and underwent emergency } \\
\text { surgical repair of the right ventricular } \\
\text { outflow tract, followed by insertion of } \\
\text { an aortopulmonary shunt in } 1 \text { patient. }\end{array}$} \\
\hline & & & & & & $\begin{array}{l}\text { On follow up, the proportional change } \\
\text { in the pulmonary annulus and } \\
\text { pulmonary arterial diameters post BPV } \\
\text { was greater than expected with } \\
\text { growth alone. }\end{array}$ & \\
\hline $\begin{array}{l}\text { BPV done in } \\
67 \text { patients with TOF }\end{array}$ & & & & & & $\begin{array}{c}\text { Forty-two patients subsequently } \\
\text { underwent total correction at } 7-79 \\
\text { (median 33) months age. There was no } \\
\text { difference in transannular patch } \\
\text { between patients adequately treated by } \\
\text { balloon dilation and those requiring } \\
\text { a shunt. }\end{array}$ & \\
\hline $\begin{array}{l}\text { Median } \\
\text { balloon/anulus ratio } \\
\text { was } 1.5\end{array}$ & & & & & & $\begin{array}{l}8(12 \%) \text { of the } 67 \text { patients died during } \\
\text { the follow-up period. }\end{array}$ & \\
\hline
\end{tabular}


Table 1. Cont.

\begin{tabular}{|c|c|c|c|c|c|c|c|}
\hline $\begin{array}{l}\text { Author and } \\
\text { Publication }\end{array}$ & Era & Age & Weight & Baseline SpO2 & $\begin{array}{l}\text { Post Balloon } \\
\text { SpO2 }\end{array}$ & Post BPV Course & Complications \\
\hline $\begin{array}{l}\text { Heusch A et al. } \\
\text { Cardiology in the } \\
\text { Young } 1999[10]\end{array}$ & \multirow{3}{*}{ 1990-1996 } & \multirow{3}{*}{$\begin{array}{l}\text { Mean age } \\
4.45 \text { months } \\
\text { (median } 2.7 \\
3 \text { days- } \\
21 \text { months) }\end{array}$} & \multirow{3}{*}{$\begin{array}{l}\text { Mean } \\
\text { weight } \\
5.02 \mathrm{~kg} \\
\text { (median 4.6; } \\
\text { 2.7-10.5) }\end{array}$} & \multirow{3}{*}{$75 \pm 8.5 \%$} & \multirow{3}{*}{$85 \pm 8.4 \%$} & $\begin{array}{l}\text { The saturation increased significantly } \\
\text { post BPV. The pulmonary annulus did } \\
\text { not change post-procedure. PA Nakata } \\
\text { index increased from } 186 \pm \\
95 \mathrm{~mm}^{2} / \mathrm{m}^{2} \text { to } 225 \pm 100 \mathrm{~mm}^{2} / \mathrm{m}^{2} \text {. }\end{array}$ & \multirow{3}{*}{$\begin{array}{c}3 \text { patients had cyanotic spells requiring } \\
\text { IV Propranolol. } 1 \text { of these patients } \\
\text { required emergency BT shunt due to } \\
\text { hypoxia. } 4 \text { patients had venous } \\
\text { thrombosis. }\end{array}$} \\
\hline $\mathrm{BPV}$ in 27 patients & & & & & & $\begin{array}{l}\text { Patients showed no significant } \\
\text { improvement in the valve hypoplasia } \\
\text { that was greater than expected with } \\
\text { growth alone. Although PA sizes } \\
\text { increased immediately after dilation, at } \\
\text { follow-up, no proportional growth of } \\
\text { the vessels was seen. }\end{array}$ & \\
\hline $\begin{array}{l}\text { Balloon/annulus } \\
\text { ratio of } 110-130 \%\end{array}$ & & & & & & $\begin{array}{l}\text { Corrective surgery was performed in } \\
22 \text { patients after a mean } 14.0 \pm \\
12.8 \text { months after palliation. Age at } \\
\text { surgery was } 21.3 \pm 13.3 \text { months. } \\
\text { Four patients were lost to follow up and } \\
\text { one died prior to corrective surgery. }\end{array}$ & \\
\hline $\begin{array}{l}\text { Sluysmans T et al. } \\
\text { Circulation } 1995 \text { [9] }\end{array}$ & \multirow[t]{2}{*}{ 1991-1993 } & \multirow{2}{*}{$\begin{array}{l}\text { 1-20 weeks } \\
\text { (median } \\
9.5 \text { weeks) }\end{array}$} & \multirow[t]{2}{*}{$\begin{array}{c}2.3-7 \mathrm{~kg} \\
\text { (median } 4.2 \text { ) }\end{array}$} & \multirow[t]{2}{*}{ Mean $78.9 \pm 8 \%$} & \multirow[t]{2}{*}{ Mean $90.1 \pm 4.5 \%$} & $\begin{array}{l}3 \text { BT shunt for increasing cyanosis at } 2, \\
3 \text {, and } 7 \text { months age and ICR later. } \\
13 \text { primary ICR at mean age of } 6 \text { months }\end{array}$ & \multirow{2}{*}{$\begin{array}{c}4 \text { increased cyanotic spells within } 1-2 \mathrm{~h} \\
\text { post BPV. } \\
1 \text { venous thrombosis of RFV requiring } \\
\text { thrombolysis. }\end{array}$} \\
\hline 19 infants & & & & & & after BPV (age range 2.5-16 months). & \\
\hline \multirow[t]{2}{*}{$\begin{array}{c}\text { Godart et al. } \\
\text { European Heart } \\
\text { Journal } 1998 \text { [24] }\end{array}$} & \multirow{3}{*}{$\begin{array}{l}\text { June } 1990- \\
\text { January } \\
1997\end{array}$} & \multirow{3}{*}{$\begin{array}{l}\text { Mean age } \\
3.3 \pm 2.7 \\
\text { months } \\
\text { (range } \\
3 \text { days to } \\
11 \text { months) }\end{array}$} & \multirow{3}{*}{$\begin{array}{l}\text { Mean } \\
\text { weight } 4.8 \\
\pm 1.3 \mathrm{~kg} \\
(\text { range } \\
2.7-8 \mathrm{~kg})\end{array}$} & \multirow{3}{*}{ Mean $76 \pm 9 \%$} & \multirow{3}{*}{ Mean $88 \pm 7 \%$} & \multirow{2}{*}{$\begin{array}{l}\text { A mean of } 6.1 \pm 4.5 \text { months after } \\
\text { dilatation, pulmonary annulus } \\
\text { increased from a mean } \mathrm{Z} \text { score of } \\
-4.1 \pm 0.9 \mathrm{SD} \text { to }-2.5 \pm 1.1 \mathrm{SD}\end{array}$} & $\begin{array}{c}\text { Four patients had transient arrhythmia } \\
\text { during inflation (atrial tachycardia in 2; } \\
\text { bradycardia in } 1 \text { and complete heart } \\
\text { block } 1 \text { ). }\end{array}$ \\
\hline & & & & & & & $\begin{array}{c}\text { Small infundibular perforation in } \\
\text { one patient }\end{array}$ \\
\hline $\begin{array}{l}33 \text { infants } \\
\text { (7 neonates) with } \\
\text { TOF underwent BPV. }\end{array}$ & & & & & & $\begin{array}{l}\text { At late follow-up (mean of } 9 \text { months } \\
\text { after dilatation, range } 3-54 \text { months), } \\
28 \text { patients underwent complete repair. } \\
\text { Trans-annular patching was required in } \\
43 \% \text { of patients. Four post-operative } \\
\text { deaths were observed, none } \\
\text { dilatation related. }\end{array}$ & $\begin{array}{l}\text { Four patients had recurrent cyanotic } \\
\text { spells leading to surgical repair within } \\
30 \text { days of BPV (three modified BT } \\
\text { shunts and one complete repair). }\end{array}$ \\
\hline
\end{tabular}


Table 1. Cont.

\begin{tabular}{|c|c|c|c|c|c|c|c|}
\hline $\begin{array}{l}\text { Author and } \\
\text { Publication }\end{array}$ & Era & Age & Weight & Baseline SpO2 & $\begin{array}{l}\text { Post Balloon } \\
\quad \mathrm{SpO} 2\end{array}$ & Post BPV Course & Complications \\
\hline $\begin{array}{l}\text { Remadevi et al. Ann } \\
\text { Pediatr Card 2008 [2] } \\
17 \text { infants. }\end{array}$ & 2004-2007 & $\begin{array}{l}\text { Median age: } \\
33 \text { days, } \\
\text { range: } \\
\text { 10-90 days }\end{array}$ & $\begin{array}{l}3.47 \pm \\
0.87 \mathrm{~kg}\end{array}$ & Mean $73 \pm 7 \%$ & Mean $90 \pm 3.68 \%$ & $\begin{array}{l}2 \text { babies developed significant } \\
\text { desaturation requiring early surgery } \\
\text { within } 6 \text { months: } 1 \text { underwent BT shunt } \\
\text { 1.5 months after BPV, another underwent } \\
\text { corrective surgery } 4 \text { months after BPV }\end{array}$ & $\begin{array}{l}\text { RVOT perforation and pericardial } \\
\text { tamponade in } 1 \text { patient. }\end{array}$ \\
\hline $\begin{array}{l}\text { Kohli et al. Pediatric } \\
\text { Cardiology } 2008 \text { [25] }\end{array}$ & \multirow[t]{2}{*}{2008} & 25 days & $1.8 \mathrm{~kg}$ & $55-60 \%$ & $95 \%$ & $\begin{array}{l}\text { Infant 1: Underwent complete repair } \\
\text { after } 1 \text { year }\end{array}$ & \multirow{2}{*}{$\begin{array}{l}\text { Patient } 2 \text { had cyanotic spells and } \\
\text { desaturations post BPV which } \\
\text { improved gradually }\end{array}$} \\
\hline 2 preterm infants & & 28 days & $1.6 \mathrm{~kg}$ & $60 \%$ & $90 \%$ & $\begin{array}{l}\text { Infant 2: Saturations of } 82 \% \text { after } 6 \\
\text { months, awaiting complete repair }\end{array}$ & \\
\hline $\begin{array}{l}\text { Wilder et al. JTCVS } \\
\text { 2017 [12] } \\
\text { BPV in } 9 \text { patients }\end{array}$ & 2000-2012 & $\begin{array}{l}\text { Median age } \\
13 \text { (range } \\
1-306)\end{array}$ & $\begin{array}{l}\text { Median } \\
\text { BSA } 0.37 \mathrm{~m}^{2} \\
\text { (range } 0.24- \\
0.78 \mathrm{~m}^{2} \text { ) }\end{array}$ & & & $\begin{array}{l}\text { Not specifically listed for BPV. } 11 \% \\
\text { underwent reoperations after primary } \\
\text { TOF repair in transcatheter intervention } \\
\text { group. Freedom from reintervention 31\% } \\
\text { for transcatheter intervention group. }\end{array}$ & \\
\hline $\begin{array}{l}\text { Kim et al. Congenital } \\
\text { Heart Disease } \\
2016[26]\end{array}$ & & & & & & $\begin{array}{l}\text { Successful BPV in } 90 \% \text {. } \\
\text { Age at total correction for BPV }\end{array}$ & \multirow{2}{*}{$\begin{array}{c}\text { Three patients needed early palliation } \\
\text { such as a modified BT shunt (two pts) } \\
\text { or infundibulectomy (one patient) after } \\
\text { BPV because of recurrent cyanotic } \\
\text { spells. The patient who underwent } \\
\text { infundibulectomy developed RVOT } \\
\text { aneurysm. }\end{array}$} \\
\hline $\begin{array}{c}31 \text { patients } \\
\text { underwent } \mathrm{BPV} \text { as } \\
\text { palliation for TOF. } \\
\text { The authors took } \\
\text { SpO2 }<85 \% \text { or } \\
\text { recurrent cyanotic } \\
\text { episodes as an } \\
\text { indication for BPV. }\end{array}$ & 2008-2014 & $\begin{array}{l}\text { Mean age } \\
26.3 \pm \\
23.6 \text { days }\end{array}$ & $\begin{array}{l}\text { Mean } \\
\text { weight } 3.6 \\
\pm 1.0 \mathrm{~kg}\end{array}$ & $\begin{array}{c}\text { Mean } 81.3 \pm \\
5.1 \%\end{array}$ & $\begin{array}{l}\text { Mean } 91.2 \pm 6.6 \% \\
\text { (reported as } \\
\text { preoperative } \\
\text { saturation) }\end{array}$ & $\begin{array}{l}\text { group: } 6.4 \pm 2.4 \text { months. } \\
\text { Body weight at operation: } 7.7 \pm 1.2 \mathrm{~kg} \text {. } \\
\text { Intraoperative pulmonary } \mathrm{z} \text {-score: } \\
-1.26 \pm 1.25 . \text { TAP required in } 29.0 \%\end{array}$ & \\
\hline $\begin{array}{l}\text { Lingaswamy et al. } \\
\text { Cardiology in the } \\
\text { Young } 2020 \text { [5] } \\
18 \text { BPV in infants }\end{array}$ & 2016-2019 & $\begin{array}{l}\text { Median age } \\
32 \text { days }\end{array}$ & $3.7 \pm 1.4 \mathrm{~kg}$ & $65 \pm 12 \%$ & & $\begin{array}{l}\text { Not specifically listed for BPV. For } \\
\text { transcatheter palliation patients: at mean } \\
\text { duration of } 7 \text { months, } 36 \% \text { complete } \\
\text { repair, } 24 \% \text { required additional palliative } \\
\text { interventions / surgery. One death due to } \\
\text { biliary atresia. Median time to next } \\
\text { intervention } 210 \text { days. }\end{array}$ & $\begin{array}{l}\text { Not specifically listed for BPV: sepsis, } \\
\text { seizures, transient CHB reported. }\end{array}$ \\
\hline
\end{tabular}




\section{Conclusions}

In conclusion, in the present era, BPV is to be considered for palliation in small infants less than 3 months with TOF presenting with severe cyanosis and/or cyanotic spells, where the institutional policy is against early surgical correction. Best results with BPV are seen in predominantly valvar pulmonary stenosis, and this may be a preferred option over other palliative strategies in preterms and newborns less than $2 \mathrm{~kg}$, in those with severely hypoxemia pre-procedure or severe cyanotic spells and hemodynamic compromise during the procedure.

Funding: This research received no external funding.

Conflicts of Interest: The authors declare no conflict of interest.

\section{References}

1. Apitz, C.; Anderson, R.H.; Dees, L. Tetralogy of Fallot with Pulmonary Stenosis. In Anderson's Pediatric Cardiology, 4th ed.; Wernovsky, G., Anderson, R.H., Kumar, K., Mussatto, K.A., Baker, E.J., Penny, D.J., Redington, A.N., Rinby, M.L., Eds.; Elsevier: Philadelphia, PA, USA, 2018; pp. 4875-5022.

2. Remadevi, K.S.; Vaidyanathan, B.; Francis, E.; Kannan, B.; Kumar, R.K. Balloon pulmonary valvotomy as interim palliation for symptomatic young infants with tetralogy of Fallot. Ann. Pediatr. Cardiol. 2008, 1, 2-7. [CrossRef]

3. Barron, D.J. Tetralogy of Fallot. World J. Pediatr. Congenit. Hear. Surg. 2013, 4, 186-191. [CrossRef]

4. Al Habib, H.F.; Jacobs, J.P.; Mavroudis, C.; Tchervenkov, C.I.; O’Brien, S.M.; Mohammadi, S.; Jacobs, M.L. Contemporary patterns of management of tetralogy of Fallot: Data from the Society of Thoracic Surgeons database. Ann. Thorac. Surg. 2010, 90, 813-820. [CrossRef]

5. $\quad$ Lingaswamy, D.; Koepcke, L.; Krishna, M.R.; Kottayil, B.P.; Sunil, G.S.; Moynihan, K.; Seshadri, B.; Kumar, R.K. Catheter-based palliation for infants with tetralogy of Fallot. Cardiol. Young 2020, 30, 1-4. [CrossRef]

6. Rao, P.S. Percutaneous balloon pulmonary valvuloplasty: State of the art. Catheter. Cardiovasc. Interv. 2007, 69, 747-763. [CrossRef]

7. Qureshi, S.A.; Kirk, C.R.; Lamb, R.K.; Arnold, R.; Wilkinson, J.L. Balloon dilatation of the pulmonary valve in the first year of life in patients with tetralogy of Fallot: A preliminary study. Br. Heart J. 1988, 60, 232-235. [CrossRef]

8. Lamb, R.; Qureshi, S.; Arnold, R. Pulmonary artery tear following balloon valvoplasty in Fallot's tetralogy. Int. J. Cardiol. 1987, 15, 347-349. [CrossRef]

9. Sluysmans, T.; Neven, B.; Rubay, J.; Lintermans, J.; Ovaert, C.; Mucumbitsi, J.; Shango, P.; Stijns, M.; Vliers, A. Early balloon dilatation of the pulmonary valve in infants with Tetralogy of Fallot: Risks and benefits. Circulation 1995, 91, 1506-1511. [CrossRef] [PubMed]

10. Heusch, A.; Tannous, A.; Krogmann, O.N.; Bourgeois, M. Balloon valvoplasty in infants with tetralogy of Fallot: Effects on oxygen sat-uration and growth of the pulmonary arteries. Cardiol. Young 1999, 9, 17-23. [CrossRef] [PubMed]

11. Sreeram, N.; Saleem, M.; Jackson, M.; Peart, I.; Mckay, R.; Arnold, R.; Walsh, K. Results of balloon pulmonary valvoplasty as a palliative procedure in tetralogy of Fallot. J. Am. Coll. Cardiol. 1991, 18, 159-165. [CrossRef]

12. Wilder, T.J.; Van Arsdell, G.S.; Benson, L.; Pham-Hung, E.; Gritti, M.; Page, A.; Caldarone, C.A.; Hickey, E.J. Young infants with severe tetralogy of Fallot: Early primary surgery versus transcatheter palliation. J. Thorac. Cardiovasc. Surg. 2017, 154, 1692-1700.e2. [CrossRef] [PubMed]

13. Petrucci, O.; O’Brien, S.M.; Jacobs, M.L.; Jacobs, J.P.; Manning, P.B.; Eghtesady, P. Risk Factors for Mortality and Morbidity After the Neonatal Blalock-Taussig Shunt Procedure. Ann. Thorac. Surg. 2011, 92, 642-652. [CrossRef] [PubMed]

14. Dohlen, G.; Chaturvedi, R.R.; Benson, L.N.; Ozawa, A.; Van Arsdell, G.S.; Fruitman, D.S.; Lee, K.-J. Stenting of the right ventricular outflow tract in the symptomatic infant with tetralogy of Fallot. Heart 2008, 95, 142-147. [CrossRef]

15. Stumper, O.; Ramchandani, B.; Noonan, P.; Mehta, C.; Bhole, V.; Reinhardt, Z.; Dhillon, R.; A Miller, P.; De Giovanni, J.V. Stenting of the right ventricular outflow tract. Heart 2013, 99, 1603-1608. [CrossRef] [PubMed]

16. Quandt, D.; Ramchandani, B.; Stickley, J.; Mehta, C.; Bhole, V.; Barron, D.J.; Stumper, O. Stenting of the Right Ventricular Outflow Tract Promotes Better Pulmonary Arterial Growth Compared with Modified Blalock-Taussig Shunt Palliation in Tetralogy of Fallot-Type Lesions. JACC Cardiovasc. Interv. 2017, 10, 1774-1784. [CrossRef] [PubMed]

17. Bertram, H.; Emmel, M.; Ewert, P.; Grohmann, J.; Haas, N.A.; Jux, C.; Kehl, H.G.; Kitzmüller, E.; Kretschmar, O.; Müller, G.; et al. Stenting of Native Right Ventricular Outflow Tract Obstructions in Symptomatic Infants. J. Interv. Cardiol. 2015, 28, 279-287. [CrossRef]

18. Cools, B.; Boshoff, D.; Heying, R.; Rega, F.; Meyns, B.; Gewillig, M. Transventricular balloon dilation and stenting of the RVOT in small infants with tetralogy of fallot with pulmonary atresia. Catheter. Cardiovasc. Interv. 2013, 82, 260-265. [CrossRef]

19. Vida, V.L.; Padalino, M.A.; Maschietto, N.; Biffanti, R.; Anderson, R.H.; Milanesi, O.; Stellin, G. The balloon dilation of the pulmonary valve during early repair of tetralogy of Fallot. Catheter. Cardiovasc. Interv. 2012, 80, 915-921. [CrossRef]

20. Robinson, J.D.; Rathod, R.H.; Brown, D.W.; Del Nido, P.J.; Lock, J.E.; McElhinney, D.B.; Bacha, E.A.; Marshall, A.C. The evolving role of intraoperative balloon pulmonary valvuloplasty in valve-sparing repair of tetralogy of Fallot. J. Thorac. Cardiovasc. Surg. 2011, 142, 1367-1373. [CrossRef] 
21. Hofferberth, S.C.; Nathan, M.; Marx, G.R.; Lu, M.; Sleeper, L.A.; Marshall, A.C.; Baird, C.W.; Mayer, J.E.; Del Nido, P.J.; Emani, S.M. Valve-sparing repair with intraoperative balloon dilation in tetralogy of Fallot: Midterm results and therapeutic implications. J. Thorac. Cardiovasc. Surg. 2018, 155, 1163-1173.e4. [CrossRef]

22. Kostolny, M.; Tsang, V.T.; Marek, J.; Derrick, G.; Cook, A.C. Neonatal tetralogy of Fallot with doubly committed ventricular septal defect and severe pulmonary valvar stenosis: A contraindication for catheter intervention? J. Thorac. Cardiovasc. Surg. 2007, 134, 258-259. [CrossRef] [PubMed]

23. Alwi, M.; Lee, J.; Sivalingam, S. Stenting of right ventricular outflow tract in Tetralogy of Fallot with subarterial ventricular septal defect: A word of caution. Ann. Pediatr. Cardiol. 2017, 10, 281-283. [CrossRef] [PubMed]

24. Godart, F.; Rey, C.; Prat, A.; Muilwijk, C.; Francart, C.; Vaksmann, G.; Brevière, G.-M. Early and late results and the effects on pulmonary arteries of balloon dilatation of the right ventricular outflow tract in tetralogy of Fallot. Eur. Heart J. 1998, 19, 595-600. [CrossRef] [PubMed]

25. Kohli, V.; Azad, S.; Sachdev, M.S.; Joshi, R.; Joshi, R.; Makram, E.R. Balloon Dilation of the Pulmonary Valve in Premature Infants with Tetralogy of Fallot. Pediatr. Cardiol. 2008, 29, 946-949. [CrossRef] [PubMed]

26. Kim, G.; Ban, G.H.; Lee, H.D.; Sung, S.C.; Kim, H.; Choi, K.H. Effects of Balloon Pulmonary Valvuloplasty as Preoperative Palliation for Tetralogy of Fallot. Congenit. Hear. Dis. 2016, 11, 315-322. [CrossRef] 